\title{
Liver Cyst Hydatid Causing Diaphragmatic Rupture: Case Report
}

\author{
Diyafragma Rüptürüne Yol Açan Karaciğer Kist Hidatiği: Olgu Sunumu
}

\begin{abstract}
Abdullah Kahraman
Department of Anestesiology, Van State Education and Research Hospital, Health Science University, Ministry of Health, Van, Turkey
\end{abstract}

\begin{abstract}
Liver cyst hydatid which is caused by a parasite called Echinococcus granulosus, is a parasitic infection that leads to endemic disease around the world. Hydatid cyst is still one of the major health problems in Turkey. Its frequency ratio is $2-6$ in 100,000 and it is placed in the liver at $60-70 \%$ ratio and in the lung at $20-25 \%$ ratio. Diaphragmatic localization is at a rate as low as $1 \%$ and is usually associated with liver hydatid cyst. In such localization of a cyst, it is not always possible for the location of the cyst to be fully determined by radiological methods. In this paper, a liver cyst hydatid case causing intraoperative diaphragmatic rupture because of its proximity to the diaphragm is presented.
\end{abstract}

Key Words: Cyst hydatid, diaphragmatic rupture, echinococcus granulosus

\section{Introduction}

Echinococcus granulosus is a parasitic disease and the causative agent of cyst hydatid disease which is common in our country and commonly found in nature. Even though it can hold onto any tissue of body, most commonly it holds onto the liver (1-3). Hydatid cyst is still one of the major health problems in our country. Its frequency ratio is $2-6$ in 100,000 and it is placed in the liver at $60-70 \%$ ratio and in the lung at $20-25 \%$ ratio (4). Diaphragmatic localization is at a rate as low as $1 \%$ and is usually associated with liver hydatid cyst. In such localization of a cyst, is not always possible for the location of the cyst to be fully determined by radiological methods $(5,6)$.

In this paper, a liver cyst hydatid case causing intraoperative diaphragmatic rupture because of its proximity to the diaphragm is presented.

\section{ÖZET}

Karaciğer kist hidatiği, Echinococcus granulosus adlı bir parazitin neden olduğu, dünya üzerinde endemik hastalığa yol açan parazitik bir enfeksiyondur. Kist hidatik Türkiye'de halen önemli sağllk problemlerinden biridir. S1klığ1 2-6/100.000 arasında olup, karaciğere (\%60-70) ve akciğere (\%20-25) oranda yerleşmektedir. Diyafragmatik yerleşim ise $\% 1$ gibi düşük orandadır ve genellikle karaciğer kist hidatiği ile ilişkilidir. Bu lokalizasyondaki bir kistin yerinin, radyolojik inceleme yöntemleriyle tam olarak belirlenebilmesi her zaman mümkün olamamaktadır. Bu yazıda, diyafragmaya komşuluğu nedeniyle intraoperatif diafragma rüptürüne neden olan karaciğer kist hidatiği olgusu sunulmuştur.

Anahtar Kelimeler: Kist hidatik, diyafram rüptürü, ekinokokkus granulozus

\section{Case Report}

Fourty years old, seventy eight $\mathrm{kg}$ male was admitted to the hospital with shortness of breath and abdominal pain complaints. In patient's radiography, right diaphragm event ration, and in abdominal ultrasonography a lesion with hypoechoic appearance compatible with 2 hydatid cysts with regular borders, the biggest of which is $6 \times 5 \times 5 \mathrm{~cm}$ as neighboring the diaphragm were observed. Preoperative patient's peripheral oxygen saturation was $95 \%$. For induction of anesthesia: $160 \mathrm{mg}$ propofol, $150 \mathrm{mcg}$ fentanyl and $40 \mathrm{mg}$ rocuronium were applied and the patient was smoothly intubated. During the surgery, one of the cysts was found to be adherent to the diaphragm. After the drainage of the cyst, it was detected that tidal volumes in ventilation decreased and there was an air leak, about which the surgeon was warned and the right diaphragm 
was detected to be perforated. After right thoracotomy, lung parenchyma and diaphragm primary were repaired through the area where they are adjacent from the baseline. After the patient was extubated postoperatively without any problems and sent to the service after ICU observation.

\section{Discussion}

Liver cyst hydatid which is caused by a parasite called Echinococcus granulosus, is a parasitic infection that leads to endemic disease around the world (1). Our country is also regarded as an endemic area for hydatid disease. The prevalence of hydatid disease in the Turkish population was reported to be $1 / 2000(6-8)$.

Cyst hydatid, although can hold on to almost every organ and system, it is most commonly seen in the liver and the lung. In a study in Australia with 1802 patients, $63 \%$ of cyst cases were in the liver while $25 \%$ in the lungs, $5 \%$ in the muscles, $3 \%$ in bones, $2 \%$ in kidneys, $1 \%$ in the brain, $1 \%$ in the spleen and in less than $1 \%$ of cases, they were in the heart, prostate and the pancreas.

Differential diagnosis in patients with scheduled operation is important. Cystic malignancies, pancreatic pseudocysts, infections and abscesses are important for differential diagnosis. The observation of septal structure and female vesicles in CT and USG is helpful in distinguishing hydatid cyst $(9,10)$.

Even though the diagnosis can be made with anamnesis, clinical findings, laboratory tests and radiological examinations, for definitive diagnosis, surgical excision for accurate and histopathologic examination are required (10).

As a result, we would like to emphasize again, how important careful monitoring of the anesthesiologist is in eliminating an important complication which could cause diaphragmatic rupture and respiratory problems in cases with liver hydatid cyst neighboring the diaphragm without leading to more serious postoperative problems or requiring a secondary surgical operation.

\section{References}

1. Şahin E, Karadayı Ş, Nadir A, Kaptanoğlu M. Diaphragmatic cyst hydatid: case report. Cumhuriyet Medical Journal 2009; 31(4): 452-455.

2. Kurt A, Onuray F, Kurt B, Çulhadaroğlu AB. Primer intramusculer cyst hydatid: case report. Cumhuriyet Medical Journal 2009; 31(4): 445-447.

3. Döleş AK, Eren ŞH, Döleş FT, Kukul MFG, Korkmaz İ, Coşkun A, et al. A case of cyst hydatid has a family history with pulmonary, hepatic and splenic involvement. Cumhuriyet Medical Journal 2009; 31(3): 288-292.

4. Uysal A, Gürüz Y, Köktürk O. Turkish Thoracic Society Parasitic lung dieases diagnosis and treatment consensus report. Turkish Thoracic Society 2009; 10: 4-12. (in Turkish)

5. Meteroğlu F, Işık AF, Elbeyli L. Complicated hydatid cyst with difficult diagnosis: two cases. Dicle Med Journal 2010; 37(3): 294-296.

6. Yuzkat N, Cegin MB. Cyst hydatid case ruptured after awake intubation causing difficult airway. Medical Science and Discovery 2015; 2(4): 278280.

7. Aytac A, Yurdakul Y, Ikizler C, Olga R, Saylam A. Pulmonary hydatid disease: report of 100 patients. Ann Thorac Surg 1977; 23(2): 145-151.

8. Balik AA, Celebi F, Başglu M, Oren D, Yildirgan I, Atamanalp SS. Intra-abdominal extrahepatic echinococcosis. Surg Today 2001; 31(10): 881884.

9. Goktas U, Yuzkat N, Isik Y, Cegin MB, Avsar A. The efficacy of prophylaxis for anaphylaxis in cyst hydatid surgery. Eastern Journal of Medicine 2014; 19(1): 58-60.

10. Pintilie DC, Panoza G, Hatmanu D, Fahrer M. Echinococcosis of the humerus. Treatment by resection and bone-grafting: A case report. J Bone Joint Surg Am 1966; 48(5): 957-961. 